\section{Management Concern for Non-COVID Children During the COVID-19 Pandemic}

Indian Council of Medical Research (ICMR) has released guidelines for coronavirus disease (COVID-19) testing in India and has been updating it frequently. The current version (April 9, 2020) [1] focusses on symptoms of COVID-19 infection and any epidemiological link (either foreign travel history, direct contact of COVID-19 patient, health worker or if patient coming from hot spot area) to maximize the sensitivity of the screening criteria.

Severe acute respiratory infection (SARI) is one of the criteria in the ICMR COVID-19 screening guidelines and it includes the presence of fever and cough and/ or respiratory distress [1], though certain additional symptoms have subsequently been added [2]. Experience from other countries has shown that SARI is not much common in pediatric COVID-19 [3-6]. Moreover, respiratory problems are common in children, and many non-COVID-19 conditions could manifest as respiratory distress even in this COVID-19 pandemic. The current ICMR COVID-19 screening criteria might be appropriate for children coming from the hot spot areas but it does not appear appropriate for children from other area, where it may lead to over-testing and undue stress on the already over-burdened healthcare system.

Moreover, barring few centers in India, both children and adult are being screened, tested and made to wait in the same isolation area till the report is available, which may lead to unnecessary exposure of children and their caregivers to COVID-19 [7]. It may also lead to delay in management of non-COVID conditions, since many facilities are not available for children in common isolation area.

There is, thus, an urgent need to reconsider screening criteria for COVID-19 in children taking in account the available evidence from our country. Furthermore, we are observing lesser number of pediatric admissions for common pediatric emergencies, and this requires vigilance as children might not be able to reach hospitals and we may encounter more deaths in children without COVID-19 [8]. We should not forget that non-COVID pediatric emergencies are still more common even in the era ofCOVID-19 pandemic.

Acknowledgement: Dr Prawin Kumar, Associate Professor, Pediatrics, AIIIMS, Jodhpur for help during preparation of this manuscript.

Funding: None; Competing interest: None stated.

Published online: May 04, 2020; PII: S097475591600173

Bharat Choudhary ${ }^{1}$ and Jagdish Prasad Goyal ${ }^{2^{*}}$ Departments of ${ }^{1}$ Trauma and Emergency (Pediatrics) and ${ }^{2}$ Pediatrics, AIIMS, Jodhpur, Rajasthan, India. *jpgoyal@rediffmail.com

\section{REFERENCES}

1. Revised Strategy for COVID19 testing in India (Version4). Available from: https://www.icmr.gov.in/pdf/covid/ strategy/Strategey_for_COVID19_Test_v4_09042020.pdf. Accessed on April 24, 2020.

2. Symptoms of Coronavirus. Available from: https:// www.cdc.gov/coronavirus/2019-ncov/symptoms-testing/ symptoms.html. Accessed on April 30, 2020.

3. Dong Y, Mo X, Hu Y, Qi X, Jiang F, Jiang Z, Tong S. Epidemiology of COVID-19 Among Children in China. Pediatrics. 2020 Mar 16 [Epub ahead of print]. Available from: https://pediatrics.aappublications.org/content/early/ 2020/03/16/peds.2020-0702.1.long. Accessed on April 30, 2020

4. Lu X, Zhang L, Du H, Zhang J, Li Y, Qu J, et al. SARSCoV-2 infection in children. N Engl J Med. 2020; 23; 382:1663-5.

5. Livingston E, Bucher K. Coronavirus Disease 2019 (COVID-19) in Italy. JAMA. 2020 Mar 17 [Epub ahead of print]. Available from: https://jamanetwork.com/journals/ jama/fullarticle/2763401. Accessed on April 30, 2020.

6. CDC COVID-19 Response Team. Severe outcomes among patients with coronavirus disease 2019 (COVID-19) United States, February 12-March 16, 2020. MMWR Morb Mortal Wkly Rep. 2020;69:343-6.

7. Kelvin AA, Halperin S. COVID-19 in children: the link in the transmission chain. Lancet Infect Dis. 2020 Mar 25 [Epub ahead of print]. Available from: https://www. thelancet.com/action/showPdf? pii $=$ S1473-3099\%2820\% 2930236-X. Accessed on April 30, 2020.

8. Balasubramanian S, Rao NM, Goenka A, Roderick M, Ramanan AV. Coronavirus disease (COVID-19) in children - What we know so far and what we do not. Indian Pediatr. 2020; April 9 [Epub ahead of print]. Accessed from: https://indianpediatrics.net/COVID29.03.2020/SA00159.pdf. Accessed on April 24, 2020. 